\title{
Environmental Landscape Management Guidelines Community Associations Can Use to Select a Landscaper and Write an Effective Landscaping Contract ${ }^{1}$
}

\section{Annemarie Post, Margaret D. Dessaint, Donald Rainey and Fred Santana ${ }^{2}$}

The guidelines presented in the Environmental Landscape Management (ELM) Guidelines for Community Associations are intended to provide an example of language that could be included in a landscape maintenance contract for existing or new community associations. Some of the text and clauses may be universally adopted while others will require modification, substitution, or omission to fit the needs of a specific project.

These guidelines have been developed by the University of Florida Institute of Food and Agricultural Sciences (UF/IFAS) Sarasota and Manatee County Extension Service, Environmental Landscape Management (ELM) program working with Community Associations. The fundamental logic guiding this process has been to create a vehicle that both improves the quality of Florida's environment and articulates the visions and concerns of individual communities.
Obtain professional design and legal advice to incorporate these suggestions into a landscape maintenance contract for your particular community. These suggestions are not intended to form a complete set of landscape guidelines, but rather to cover many of the points that are commonly missed. Additional help may be available through your local UF/IFAS Extension Service office.

\section{Environmental Landscape Management (ELM) Guidelines}

\section{Selecting a Landscape Maintenance Contractor}

Landscape maintenance is often a major expense in community association management since the appearance of the landscape is important to the community's reputation and to the protection of property value. By properly contracting for these

1. This document is ENH1080, one of a series of the Environmental Horticulture Department, Florida Cooperative Extension Service, Institute of Food and Agricultural Sciences, University of Florida. Original publication date October, 2007. Visit the EDIS Web Site at http://edis.ifas.ufl.edu.

2. Annemarie Post, Extension Agent, Sarasota County Extension; Margaret D. Dessaint, Extension Agent, Commercial Horticulture, Manatee County Extension; Donald Rainey, Extension Agent, Commercial Horticulture, Sarasota County Extension; and Fred Santana, Integrated Pest Management (IPM) Coordinator, Sarasota County Extension, Department of Environmental Horticulture, Florida Cooperative Extension Service, Institute of Food and Agricultural Sciences, University of Florida, Gainesville, FL 32611.

The use of trade names in this publication is solely for the purpose of providing specific information. UF/IFAS does not guarantee or warranty the products named, and references to them in this publication does not signify our approval to the exclusion of other products of suitable composition.

The Institute of Food and Agricultural Sciences (IFAS) is an Equal Opportunity Institution authorized to provide research, educational information and other services only to individuals and institutions that function with non-discrimination with respect to race, creed, color, religion, age, disability, sex, sexual orientation, marital status, national origin, political opinions or affiliations. U.S. Department of Agriculture, Cooperative Extension Service, University of Florida, IFAS, Florida A. \& M. University Cooperative Extension Program, and Boards of County Commissioners Cooperating. Larry Arrington, Dean 
services, an association can save money and extend the life of plants.

Insist on current references from prospective contractors. Contact each reference and, if possible, tour the grounds. Realistic specifications and maintenance schedules are critical to a contractor's performance. All quotes should be based on one set of specifications. Additional proposals should be considered if they are submitted as an addendum to the specifications.

During the selection process, the association should consider the quality of a landscape maintenance contractor's personnel, because satisfactory performance requires a well-supervised, competent staff.

\section{The Contract}

The landscape maintenance contractor is a firm that offers complete maintenance services for the landscape or, in some cases, a firm that offers basic landscape maintenance services (mowing, pruning, edging, weeding,) and uses a subcontractor for specific services (tree care, fertilization, insect and disease control). A good contractor is the best option for maintaining community landscapes, and a service contract ensures that proper and timely care is given to all plants, including turf and woody ornamentals such as shrubs, trees and palms. A realistic budget and specially trained professionals are crucial elements of landscape protection.

\section{Benefits of the Contracted Service}

- A landscape maintenance contractor maintains landscapes for plant health and longevity.

- Company personnel have expertise in horticulture, including evaluation and treatment of plant problems (insects, diseases, weeds, nutritional deficits); proper chemical usage; mowing, pruning and edging methods; and other detailed maintenance requirements. The contractor can, therefore, remedy landscape problems and outline a detailed landscape maintenance program.

- A contractor with specially trained staff, such as a certified arborist or pest control operator, is even more effective but may be more expensive at first. However, the additional cost in contracted maintenance fees is a small price to pay compared to the cost of replacing turf and landscape plants damaged by disease and insects. Additionally, a certified arborist can identify hazardous trees on the property that represent a liability to the association.

- Hiring a contractor will reduce capital outlay for equipment and the associated expenses of equipment maintenance. Mowers, edging equipment, spreaders, sprayers, and specialized hand tools are needed to properly maintain planted beds and turf areas. A contractor also understands the capabilities of the equipment and will plan schedules to ensure optimum performance.

- The improved survival rate of plants is another benefit. By carefully drafting the contract specifications, the association can obligate the contractor to warrant newly planted shrubs and trees. A contractor that enters into an agreement in which plants are guaranteed will make an effort to ensure their survival.

\section{Drafting Specifications and Schedules}

Properly drafted specifications and maintenance schedules are critical. The specifications should outline the services the contractor will perform, while the maintenance schedules should include a time frame for the various performance requirements contained in the specification. Specifications should include performance criteria and warranties.

Writing specifications can be difficult, especially when they are being drafted for the first time. One approach is to seek assistance from a horticulturist, a landscape maintenance contractor, a landscape architect (local, with field experience), or your local UF/IFAS Extension Service.

Another method is to form a landscape committee to research and write the specifications. An advantage of this approach is that the association will end up with an informed committee, while the primary disadvantage is that without proper expertise and time, the specifications may be written incorrectly. 
A third method is to get samples of specifications from several reputable contractors and select the parts that are best for your situation.

\section{Performance Criteria}

The performance criteria should outline the contractor's specific activities in the areas of turf management; shrub, tree, palm and bed maintenance; litter removal; and cleanup. The performance criteria should reference all materials and products to be used and provided by the contractor. Details regarding types of fertilizer, pesticides (insecticides, fungicides, herbicides), and mulch should be included here with some provisions for equivalent alternatives.

If using an all-inclusive service contract, be sure to include a severance clause so that the association can terminate one of the services without affecting the rest. If possible, draw separate contracts for each service rather than using the all-inclusive service contract. When contracting various secondary services from one entity, the association must clearly state all additional cost for those services.

If the association chooses to appropriate funds for immediate improvements, an addendum to the contract should be written. Both the association and the contractor should understand that flexibility is required in certain situations to ensure proper care and maintenance of the landscape.

\section{Warranties and Guarantees}

The specifications should state the warranties and guarantees expected of the contractor. This will provide maximum protection to the association and assure that unrealistic demands are not placed on the contractor. The association may make more demands if the maintenance contractor installed the original landscape. In this case, the original warranty provided at the time of installation can be coupled with the warranty and guarantees section of the specifications to make sure that the contractor will maintain proper growth and prevent loss of plants.

\section{Maintenance Schedule}

A specific maintenance schedule should be included in the landscape maintenance contract. The schedule should state the time frame for the accomplishment of various tasks by the contractor. It should include, at least, the following:

- Mowing and edging

- Pruning shrubs, palms and trees

- Fertilization of lawn and landscape beds

- Insect and disease control

- Weed control

- Maintenance of the irrigation system

The maintenance schedule covers the entire contract period, stating in detail when the contractor is expected to perform the various tasks. The schedule can be used as a management tool to monitor the contractor's performance. Contractors are usually expected to perform specific tasks - under normal climate conditions - within a two- to three-week period. Therefore, the time frame stated in the maintenance schedule should be in monthly increments. This time period provides flexibility for the contractor.

The maintenance schedule should not be treated as a mere guideline. Only natural disasters should be accepted as a cause for deviation from the maintenance schedule.

\section{Insurance Requirements}

Insurance requirements, including performance evaluation, legal structure and language, must be clearly defined in the contract. It is important that the contractor's and the association's insurance cover all reasonable exposures to liability risks. First, the association should carry adequate insurance on their own general liability policy. Although the limits will be up to the board of directors, the policy at the very least should be on a "comprehensive" form and an "occurrence" basis. The policy should include premises and product/completed operations coverage.

Second, the contractor policy should include the same form, basis, and coverage as the association. In addition, the policy as well as certificates provided should include the following coverage or endorsements: aggregate applies per project; XCU (explosion, collapse, and underground hazards) 
exclusion deleted; the association, its members, guests, and agents named as additional insured; contractual liability; and a hold harmless (indemnification) agreement in favor of the association for bodily injury, personal injury and property damage. Limits should be adequate for the extent of the services provided.

The insured subcontractor selected by the contractor must be licensed to do business in the association's jurisdiction. The association should require the contractor to carry workers compensation insurance with employers liability limits of at least $\$ 1,000,000$ and a waiver of subrogation for the work or job performed. Certificates should be sent to the association's insurance agent for review. The contractor's insurance requirements can be placed in the legal body, in the specifications under the heading of general requirements, or in an insurance section. The association should ensure that the certificates include a 30-day notice of cancellation or non-renewal to the association. The association should stipulate the amount of time the contractor has to remedy the loss of coverage. The contractor should not be allowed on-site during this time period.

\section{Homeowner Communication}

The board of directors should communicate the terms and details of the contract, along with the board's performance expectations of the contractor, to the homeowners. If this is handled correctly, this step usually prevents unwarranted criticism from owners and board members.

The most important aspect of owner communication is to state clearly what immediate improvements are expected and when these will be accomplished by the contractor. The owners must also be informed of the board's decisions regarding any additional funds needed for immediate improvements. If the new contractor is a replacement, reasons for the change should be explained.

Communication of these issues and of the contract details to the owners will aid in the contractor's success.

\section{Bidding and Evaluating Bidders}

Major factors to consider when researching landscape maintenance contractors are experience, references and facilities.

One of the benefits of contract service is the personnel's specialized expertise in the landscape maintenance field. The contractor's key employee should be an ornamental horticulturist, whose knowledge and training is vital to landscape problem-solving. The remainder of the staff should be educated or experienced in landscape maintenance. The ideal staff includes a horticulturist, an irrigation specialist and an agronomist. The horticulturist specializes in flowers, shrubs, palms and trees. The agronomist specializes in soil and turf management and may be beneficial for an association with large areas of turf. The size of the firm has little to do with the competency or capability to perform, and it is best not to place too much emphasis on size. Satisfactory performance is usually the result of adequate supervision. Contractors should provide references, preferably from associations of similar size and landscape. The association should conduct a thorough investigation and each reference should contain three key items. They are:

- the length of time the contract has been in force,

- historical data related to any price increases, and

- a specific name to contact for more information.

References should be asked to rate the overall performance and satisfaction, specific areas of performance (bed maintenance, turf management, pruning, and edging), adherence to schedules, complaint procedures, and response time.

Visit the contractor's office and other facilities to observe the contractor's total operation. Ask to see the shop the contractor uses for routine equipment maintenance and the repair parts inventory. If the contractor uses an outside repair shop, find out the name and check the contractor's repair history with the shop. The visit will also allow the board of 
directors or manager to meet the contractor's personnel. If the entire crew is not available, ask to meet the supervisor or foreman.

\section{Bidding the Contract}

The final stage in the selection of the landscape maintenance contractor is the bidding process. The association should secure three to five bids. There are several ways to locate good landscape maintenance firms. Contact local landscape supply firms, the Association of Landscape Architects, or a nurseryman's association. Also ask other community associations for recommendations.

The association representative should conduct a detailed, on-site inspection with each contractor. This inspection reduces the chance of misunderstandings and increases the likelihood of a realistic contract. It allows both the contractor and the representative to visually observe specific areas of concern in the existing landscape. It will also give the contractor an opportunity to outline the time frame for phased-in improvements or to give the association recommendations and any additional cost estimates for immediate improvements. The association should document items noted during this inspection.

The actual bidding process; determining the time frame allowed for bid submission; the form of the bids (sealed or unsealed); and people responsible for receiving, opening, and reviewing the bids, can be handled at the discretion of the association, by the manager, the grounds committee or the board of directors. Each association should adopt the method that best suits its particular needs and organizational structure.

Before selecting the landscape maintenance firms that will be allowed to bid, conduct a credit check; obtain a rating from the Better Business Bureau, and contact local landscape supply firms to check payment history.

\section{Selecting the Best Bid}

After receiving the bid, review and select the contractor. Establish a checklist for each bidding contractor to determine the most acceptable quote. The checklist structure should consider the contractor's adherence to the specifications, alternative proposals, references, and price. The final decision should be based on the checklist.

\section{Legal Review}

Before accepting a contract, the association's attorney should review its legal structure and wording since requirements such as cancellation and termination laws, contract term period requirements, severability, and other matters differ from state to state. Each association has unique requirements, and sample contracts from other associations may not apply to the situation or may not comply with state law. The association board of directors or manager should review the contract with the attorney. The attorney should be present during final acceptance of any contract, especially if any items are negotiated.

\section{Environmental Concerns}

Protecting the environment has become a major issue for both public health and financial reasons. Concern about the harmful environmental impact on both surface water and groundwater quality caused by run-off and leaching of nitrate and phosphorus dictates sound fertilization practices. One of the best ways to reduce pollution is to use caution when applying fertilizers. Heavy summer rains exacerbate the problem of nitrate leaching or run-off.

Over-fertilization with nitrogen in the summer also encourages insect and disease problems. Companies hired to fertilize the landscape shall have Florida Green Industries Best Management Practices (BMPs) certification and shall also conform to local and state ordinances. Information about the Florida Green Industry Best Management Practices can be found at http://www.dep.state.fl.us/central/Home/

MeetingsTraining/FLGreen/FLGreenIndustries.htm.

Select a contractor who uses an Integrated Pest Management (IPM) approach. IPM involves treating the landscape as an ecosystem. Rather than routinely scheduling pesticide applications, IPM focuses on regular monitoring and prevention of pests or their damage. It combines several methods of pest management that reduce impacts on human health, non-target organisms, the environment, and surface and groundwater. Monitoring (sometimes called scouting or horticultural inspections) is an essential 
part of landscape maintenance. An IPM approach determines if and when pest management measures are needed by regularly monitoring pests and their natural enemies. IPM employs physical, mechanical, cultural, biological, and chemical controls. It is important that turf and other vegetation be inspected during each visit for indications of pest problems. Pesticides should only be used when necessary and the decision to apply a pesticide must be supported by monitoring records (IPM Field Reports). Pesticide applications should be targeted to the area suffering damage, not to the entire landscape. Materials least harmful (least toxic) to the environment, based on UF/IFAS recommendations, should be used before using more harmful (more toxic) materials, and treatments should be evaluated to determine their effectiveness.

Contract specifications should make the contractor completely responsible for any environmental cleanup resulting from chemical or fuel spills that occur in the course of business. The specifications should require the contractor to select a designated area for all equipment refueling and servicing. Any mixing or other handling of chemicals should occur in this "mix" area. Contractors should also be required to immediately clean any equipment such as sprayers and properly dispose of the waste. It is critical that the contract indicate how fuels and oil, fertilizers, and all normal landscape chemicals will be stored.

Grass clippings and leaves fill nearly 20 percent of the total volume of the nation's landfills. Turf clippings shall be left on turf areas to recycle the nutrients in them. Fallen tree leaves can be used as a base-mulch, which can then be top-dressed (if desired) with a commercial mulch.

\section{Contractor Performance Evaluation}

The contractor performance evaluation is the final ingredient of a successful contract. The association should state in the contract body or in the specifications section that it will designate one person as the representative who will give the contractor direction. This establishes a communication link when any problems arise during the contract term.
The contract language should state to whom, how, and when regular reports are to be made to the association. Set up a method that is agreeable to all parties for work orders, preferably in writing, and set up an acceptable time frame for resolution, also in writing. For large landscapes it is best to require the contractor to report directly to the board of directors or landscape committee.

The content of the contractor's report should include a review of maintenance activities accomplished since the last report; planned activities for the immediate future; a discussion of any deviations from the specifications and schedules; unusual circumstances or problems encountered; and recommendations for improvements or changes in the specifications, schedules, or landscape components.

The last performance consideration is termination for failure to perform satisfactorily. The language in this part of the contract should be written or reviewed by the association's attorney. The contract should also state the amount of time the contractor has to remedy any serious performance deficiencies.

\section{Landscape Maintenance Contract Specifications}

\section{Performance and Activities}

The performance criteria should outline general standards and scope, and the contractor's specific activities in the areas of turf management; shrub, tree, and bed maintenance; litter removal; and cleanup.

\section{General Standards}

\section{Contractor shall:}

- Show knowledge of location (specific site conditions)

- Point out pre-existing conditions and plan for corrective actions

- Have a certificate of insurance with required coverage (including Workers Compensation) 
- Provide written reports (monthly, due date, content, service tickets)

- Provide all materials, tools, equipment and labor

- Perform at highest standards

- Have a Green Industries Best Management Practices (BMPs) certificate of completion offered by University of Florida IFAS Extension Service.

- Perform according to county, state and federal regulations (including any related to fertilizers and pesticides)

- Avoid vague language

\section{Scope}

The contractor shall furnish all labor, supervision, equipment and materials as necessary to provide complete maintenance and irrigation of all shrubs, trees, palms, ground covers, annual and perennial plants and lawns, and shall provide such other work as may be required by these specifications, to maintain the landscape in an attractive condition throughout the year. The supervisor shall have experience in ornamental horticulture and Environmental Landscape Management (ELM) practices. ELM emphasizes proper cultural practices coupled with regular inspections for early warning signs of problems and the use of the most environmentally friendly methods to solve them. The work to be completed in this section includes:

\section{Turf Care}

\section{Mowing and Edging}

- All grass must be maintained at the recommended height (see Appendix I), using mulching, rotary type, mowers.

Mowing shall be done once each week during seasons of active growth (April through October). From November through March, mowing will be done only as necessary to keep turf areas neat and to keep weeds from flowering and setting seed. Not more than one-third (1/3) of the leaf blades shall be removed per mowing. Mower heights are measured with mowers on a flat, paved surface. Mower blades must be sharp at all times to provide a high quality cut. All edging will be done at the time of mowing.

- Clippings will be swept, blown, or vacuumed from sidewalks, patios, curbs, and roadways immediately after mowing or edging. They will not be blown into storm drains. Blowers shall not be used in parking lots. Any damage to vehicles, including damage from vegetative debris and grass clippings, is the responsibility of the contractor.

- Mowing must be directed away from water bodies and impervious surfaces. Turfgrass clippings are a source of slow-release nitrogen. Leaving the clippings, rather than removing and bagging them, reduces both fertilization needs and the amount of plant material that must be disposed. Note: no plant material is allowed in Florida landfills. No readily visible clumps shall remain on the grass surface after mowing. Large clumps of clippings will be raked into the turf or immediately collected and removed by the contractor immediately.

\section{Fertilization}

UF/IFAS guidelines for turfgrass fertilization shall be followed. These can be found in UF/IFAS publication ENH962, "Figuring Out Fertilizer for the Home Lawn" by L.E. Trenholm and J.B. Unruh (http://edis.ifas.ufl.edu/EP221).

- Turf shall not be fertilized when heavy rain is expected. A "Ring of Responsibility" will be left around or along water bodies. The Ring of Responsibility shall extend at least 10 feet from the edge of the water.

- Fertilizers must contain slow-release nitrogen and will be applied at the rate of no more than one pound of nitrogen per 1,000 square feet. This is calculated by dividing the percentage of nitrogen into 100. (Example: If the ratio 15-0-15 is used, then 6.6 pounds of the fertilizer will be spread over 1,000 square feet of lawn area).

- Florida soils are naturally high in phosphorus; therefore a soil test should be used to determine if this nutrient should be applied. If the soil test 
indicates that phosphorus application is needed, apply 0.25 pound of phosphorus per 1,000 square feet, not to exceed 0.50 pound annually.

- It is recommended that iron be applied in summer to provide dark green color without stimulating excessive growth. Use ferrous sulfate ( 2 oz. in 3-5 gallons water per 1,000 square feet) or a chelated iron source.

- The fertilizer analysis, rate of application, and watering in the product, must be specified in the contract.

- Fertilization scheduling shall not exceed the recommendations from the UF/IFAS Extension Service and should comply with the Green Industries Best Management Practices, and state and local ordinances.

\section{Insect and Disease Control}

- Select a contractor that uses Integrated Pest Management (IPM) for insect, disease, and weed control (see Appendix II).

- The decision to apply a pesticide must be supported by monitoring records (IPM Field Reports). Applications of insecticides and fungicides will be coordinated with the irrigation schedule.

- Pesticides may only be applied by a licensed pesticide applicator or trained technician under licensee's supervision, and must follow laws and rules under Florida Structural Pest Control Act, Chapter 482 under Florida Department of Agriculture and Consumer Services.

- The treatment of fire ant mounds, fleas and ticks sometimes falls outside the annual contract and may require an additional bid.

\section{Weed Control}

Weeds are often the result of thin, unthrifty turfgrass. Cultural practices that encourage deep, healthy roots combined with proper fertilization and irrigation may alleviate this problem. However, treatments with a pre- or post-emergence herbicide may be necessary.
- Pre-emergent herbicides control weeds before germination. The products selected for control must be used at the recommended label rates.

- Post-emergent herbicides control weeds after germination. They must be applied according to the label instructions, especially those regarding Florida temperatures.

- The control of sedges sometimes falls outside the annual contract and may require an additional bid.

\section{Irrigation}

Irrigation systems must be operated in an efficient manner that minimizes run-off and percolation beyond the root zone. In general, irrigation should be used only when necessary. The use of automatic rain shut-off devices is required by state law (effective May 1, 1991). See Appendix IV for more detailed information.

\section{6. $\underline{\text { Renovation }}$}

Turf renovation falls outside the annual contract and will require an additional bid. It is important to determine the cause of grass decline to determine whether turfgrass or a low-maintenance groundcover is the better option for the area. Renovation should coincide with the rainy season to reduce the irrigation demand for plant establishment.

\section{Shrub, Palm and Tree Maintenance}

\section{Pruning}

Pruning is the selective removal of plant parts and branches to improve health, control growth, or enhance fruiting, flowering, or appearance.

Corrective pruning shall be done to maintain the natural shape and characteristics of the species.

- Shrubs shall be lightly pruned based on the need of each species. Certain flowering shrubs have specific times when they should or should not be pruned.

- Palms need their foliage for photosynthesis and energy production. It is preferable not to remove live, healthy fronds. Discoloration of the lower palm fronds can be a symptom of natural senescence (normal aging), but can also be 
caused by nutritional deficiencies. Proper fertilization (e.g., potassium and magnesium) prevents premature leaf yellowing. There are several reasons for pruning palms:

1. Removing dead and dying lower fronds improves the appearance of a palm.

2. Dead and dying fronds and loose petioles are often weakly attached and can place people and property at risk should they fall. Removing dead and dying palm fronds will reduce this risk.

3. Flower and fruit clusters, especially in public landscapes, can be messy as well as hazardous. In addition, some palms generate large numbers of seedlings near the plant. Removing flowers or fruit reduces the number of potential seedlings.

Avoid removing fronds that are growing horizontally or growing upward (i.e., retain all fronds within a "9AM - 3PM" frame). Fronds should be cut close to the petiole base without damaging living trunk tissue. Dead fronds may be removed with a small chain saw, and developing flower and fruit stalks that emerge between live fronds shall be cut with a hand saw to avoid injury to the surrounding palm fronds. The cost of pruning palms over 15 feet tall and the removal of suckers from clumping palms usually falls outside the annual contract and may require an additional bid.

- The central leaders (trunks) of all trees shall be maintained (no topping, hat-racking, or "lollipop" shapes). Interfering or crossed limbs shall be removed. All branches shall be removed using "collar cuts." Sucker growth at the base of trees shall be removed by hand. Herbicides shall not be used for this purpose. Aesthetic pruning shall consist of the removal of dead or broken branches as often as necessary to have trees appear neat at all times. Branches and limbs shall be kept a minimum of two feet away from all buildings, especially roofs. Trees by sidewalks and parking lots shall be maintained to provide clearance for pedestrians and vehicles. Pruning of large trees over 15 feet tall falls outside the annual contract and may require the contractor to use the services of an ISA-certified arborist at additional cost. The removal of living or dead trees will also require an additional bid and may require a tree removal permit from the local municipality.

\section{Fertilization}

- Established trees and shrubs (those over three years old) generally do not need supplemental fertilizer unless they are deficient in a specific nutrient. Over-fertilization encourages excessive growth that results in increased demand for pruning.

- During the establishment phase, shrubs, trees, and ground covers shall be fertilized with a slow-release fertilizer at the rate of no more than one pound of nitrogen per 1,000 square feet of planting area. The fertilizer shall contain both nitrogen and potassium, in slow-release form. A soil test should be used to determine if magnesium $(\mathrm{Mg})$, and minor elements such as iron and manganese are needed. If the soil test indicates that these elements are needed, fertilizer should contain 3\% - 5\% magnesium $(\mathrm{Mg})$ and $1 \%-2 \%$ of iron and manganese.

- Fertilizer type depends on soil conditions. Nutritional deficiencies may develop due to soil conditions, such as alkaline $\mathrm{pH}$ or compacted soils, or damaged and diseased root systems. Deficiencies of specific nutrients shall be treated with applications of the needed nutrient in accordance with UF/IFAS recommendations until deficiencies are corrected.

- Fertilizer shall be broadcast around plants uniformly, but will never directly contact stems and trunks. Fertilizers shall be spread evenly under tree canopies (from the outer edge drip line inward).

- Palms shall be fertilized with a granular, slow-release fertilizer three to four times per year. An acceptable formulation is 8-2-12-4 (N, $\mathrm{P}, \mathrm{K}, \mathrm{Mg}$ plus micro-elements). Mature palms require five pounds of fertilizer per application. For palms under ten feet tall, two pounds per application will be adequate.

- Palms' nutritional requirements differ from those of other landscape plants. They suffer quickly and conspicuously from inadequate 
mineral nutrition, whether due to insufficient or incorrect fertilization. Deficiencies in potassium, magnesium, manganese, and boron are much more prevalent and serious than nitrogen deficiency. Potassium deficiency is the most widespread and serious of all disorders in Florida palms. Magnesium deficiency is also quite common in Florida palms, but especially in Phoenix species. Manganese deficiency or "frizzletop" is a common problem in palms growing in the alkaline soils that cover much of south Florida. The cost of monitoring and correcting these problems may be built into the contract or it may be considered an additional, external cost.

- Fertilization scheduling shall not exceed the recommendations from the UF/IFAS Extension Service and should comply with the Green Industries Best Management Practices, and state and local ordinances.

\section{Insect and Disease Control}

As mentioned above, contractor will use Integrated Pest Management (IPM) practices as mentioned in Appendix II. The contractor must adhere to State of Florida regulations governing the use of pesticides.

\section{Weed Control}

All areas around trees, palms, and shrubs must be mulched and maintained weed free. During months of active growth, weed control must be accomplished every week.

- Ornamental beds, hedge areas, and tree basins will be kept weed free by such mechanical means as hoeing or hand pulling, and/or by herbicide applications. Through proper cultural practices of weekly hand pulling and selective spot treatments with herbicides, use of labor and herbicides will eventually be greatly reduced.

- Where chemical weed control is thought to be necessary, contractors are encouraged to use the least toxic, target-specific materials and methods.

- The mulched areas around trees and palms shall be kept clean of grass and weeds to a minimum of twenty-four inches from the trunk. Large trees and plant groupings will require larger mulched areas. Ideally, the mulched area is equal to the drip line on a large canopy tree. Edging around trees and shrub beds shall be performed after each mowing using hand labor or edgers.

- String trimmers will be used for year-round weed control in sidewalks, patio areas, parking lots, curbs, and other hard-scaped areas. This will be done weekly in order to control weeds without herbicide application.

- Mowers and string trimmers can damage trees. Trunks bumped and injured by mowers can become stressed, and areas of damage serve as entry points for disease and decay. The whipping action of the nylon string on a trimmer can de-bark a young tree and kill it. Careful use of string trimmers and mowers in the landscape is imperative.

- The contractor shall be responsible for replacement of ornamental plants killed or damaged by herbicide application or mechanical equipment.

\section{Irrigation}

Irrigation should be used only when necessary. The use of automatic rain shut-off devices is required by state law (effective May 1, 1991). For more detailed information, see Appendix III.

\section{Mulch}

Mulches are an increasingly important part of the Florida urban landscape. A mulched landscape reduces soil and water run-off, holds moisture in the root zone and inhibits weeds.

- Mulch shall be maintained at a depth of at least two inches. When additional mulch is necessary, the contractor should present a separate bid for approval.

- The use of mulches made from sustainable materials such as recycled hardwood mulch, Melaleuca (punk) trees, Eucalyptus, pine needles, and pine bark is recommended. Grade B cypress mulches made from whole tree wood are not permitted because harvesting from the wild depletes cypress wetlands. 
- A 2-inch space should be left between the trunks of plants and the mulch.

- If mulch is installed improperly, the contractor is responsible for correction, at no additional charge. Any equipment (e.g., Bobcat), necessary to facilitate mulching shall be included in the price submitted.

\section{Litter and Debris Removal}

Contractor shall pick up all debris generated while maintaining the property. Other debris from hurricanes, freezes and other natural events fall outside the annual contract and may require a separate bid.

\section{Warranties}

Contractor shall replace, at his/her expense, any plants or turf that deteriorate or die due to his, or his employees', actions. This does not include losses due to damage from acts of God, vandalism or human abuse other than that caused by the contractor. Palms and citrus are special cases because these species are susceptible to certain lethal diseases not normally related to cultural practices.

\section{Appendix I}

\begin{tabular}{|l|l|}
\hline St. Augustine & $3-4$ \\
\hline St. Augustine (Dwarf & $1.5-$ \\
varieties) & 25 \\
\hline Bermuda & $0.5-$ \\
\hline Bahia & 3.5 \\
\hline Seashore Paspalum & $1-2$ \\
\hline Zoysia & $1-3$ \\
\hline
\end{tabular}

\section{Appendix II}

One of the most important components of an IPM program is monitoring (scouting, horticultural inspection). In addition to detecting a pest problem, monitoring helps to keep track of pest populations over time. Early detection helps confine outbreaks and frequently allows for better timing of control measures. Monitoring can be done bi-weekly, monthly, or bi-monthly, depending on the level of service preferred by the association. Identification is crucial to preserving beneficial insects. It is important that the contractor becomes familiar with the turf areas under his or her control in order to learn where problems might first appear. The contractor should identify potential pests in landscaped areas on each visit and monitor for indications of damage or harm to the landscape. No pest management treatments should be conducted unless the problem has been scouted and identified.

Blanket applications of pesticides and scheduled preventive spray applications are inappropriate. The goal is to prevent pest problems by regular monitoring, proper plant selection and sound cultural practices, (correct pruning fertilization and irrigation). Preventing pesticide exposure and injury to the environment is an important consideration in the landscape setting. The focus must be prevention or suppression of pest problems with minimum impact on human health, non-target organisms, and the environment (particularly surface and groundwater). Pest management strategies that include the use of cultural practices along with bio-pesticides, biologicals, and other least toxic approaches, are considered safer than strategies that use more toxic chemical treatments, and should be used as much as possible. Contact your local UF/IFAS Extension Service for information on pest identification and management as well as the least toxic materials available to control them. The effectiveness of a pest management strategy can vary from one pest to another and even from one year to the next in the same location. Keep good records to track the efficacy of treatment.

As an aid in the detection of pests and to determine when and where action should be taken to prevent damage, IPM researchers have developed the Action Threshold (AT) or economic threshold for turf pests. The AT is the point at which action should be strongly considered. The ATs for turf pests are shown below:

\begin{tabular}{|l|l|l|}
\hline Pest & $\begin{array}{l}\text { Number } \\
\text { per sq. ft. }\end{array}$ & $\begin{array}{l}\text { Monitoring } \\
\text { method }\end{array}$ \\
\hline Armyworms & $3-4$ & visual, soap flush \\
\hline Billbugs & 6 & visual \\
\hline Chinch bugs & 20 & flotation, soap flush \\
\hline Cutworms & 1 & visual, soap flush \\
\hline White grubs & $3-4$ & visual \\
\hline Mole crickets & $1-2$ & visual, soap flush \\
\hline Sod webworms & $5-8$ & visual, soap flush \\
\hline
\end{tabular}


Soap flushes are a useful tool for detecting caterpillars, chinch bugs and mole crickets during their infestation periods. The technician will mix 2 tablespoons of Joy ${ }^{\circledR}$ or any non-degreasing liquid dishwashing soap in a gallon jug of water and then equally distribute it over a one-by-two foot area of turf. The soap solution is irritating to the insects and flushes them up where they can be more easily counted. For white grubs and billbugs, the technician will cut a one-by-one foot area of turf about 2 inches deep and roll it back to check for insects and root damage. Whether visual or soap flush methods are used, at least 2 or 3 areas on the edges of damaged spots must be monitored.

\section{Appendix III}

Irrigation systems are not designed to replace rainfall, but rather to supplement rainfall. They should apply $3 / 4$ inch water per irrigation cycle. The irrigation system should be calibrated so that all areas receive adequate coverage. Irrigation frequency and timing must comply with local water restrictions. The irrigation schedule shall be adjusted seasonally, based on weather conditions. The use of automatic rain shut-off devices is required by state law (effective May 1, 1991). Micro-irrigation should be used for tree and shrub beds, and these zones should be separated from lawn areas to allow for irrigation efficiency in these different areas.

Poorly designed irrigation systems often provide poor coverage and cause problems with under- and over-watering of areas within a zone. The contractor should point out deficiencies and recommend solutions. Cost for parts, labor, equipment and materials for other repairs falls outside the annual contract and requires an additional bid. Normal maintenance, preferably monthly should include:

- inspecting for broken, clogged or non-functioning heads, and valves,

- adjusting heads for coverage,

- replacing head filters,

- adjusting timer clocks every season,
- removing plant growth and turf around spray heads,

- capping irrigation heads in areas with mature trees and shrubs

\section{Helpful Resources}

- Florida Green Industry Best Management Practices for Protection of Water Resources in Florida, 2002. http://www.dep.state.fl.us/central/Home/ MeetingsTraining/FLGreen/ BMP_Book_final.pdf

- The Florida Lawn Handbook; Best Management Practices for Your Home Lawn in Florida, Laurie E. Trenholm and J. Bryan Unruh, University Press of Florida, 2005.

- A Guide to Florida-Friendly Landscaping; Florida Yards \& Neighborhoods Handbook, 2006. http://fyn.ifas.ufl.edu/.

- UF/IFAS Extension Publications: http://edis.ifas.ufl.edu/

- Your Florida Landscape; a Complete Guide to Planting and Maintenance, Robert J. Black and Kathleen C. Ruppert, University Press of Florida, 1998.

\section{Acknowledgements}

We would like to thank Dennis Alexander of Sarasota County Public Works Facility Maintenance, Tom Fields of Arrow Environmental Services, Paul Flaig and Barry Scarr of Scarr Insurance Group, Diana Graham of the Fairway Woods Homeowners Association, Jo Hanson (UF/IFAS Sarasota County Extension Master Gardener), and Michael Thomas of the Florida Department of Environmental Protection, for their input. 


\section{ENVIRONMENTAL LANDSCAPE MANAGEMENT (ELM) SAMPLE INSPECTION REPORT}

Name:

Date:

Weed

Control:

Turf:

Tree:

Palms:

Shrubs:

Nutritional

Requirements:

Pest

Problems:

Parking Lot \&

Walks:

Miscellaneous:

Landscape Maintenance

Contractor:

Inspected By:

Additional

Comments: 


\section{INTEGRATED PEST MANAGEMENT (IPM) \\ SAMPLE MONTHLY FIELD REPORT}

LOCATION REPORTING ON:

REPORTING MONTH:

COMPANY NAME:

NAME/TITLE OF PERSON MONITORING:

PEST PROBLEMS IDENTIFIED ON:

TURF: SHRUBS:

TREES:

PALMS:

\section{PEST IDENTIFICATION:}

WEEDS (List types)

PATHOGENS (List plants \& disease)

INSECTS (List plants \& insects)

\section{LEAST TOXIC PEST CONTROL STRATEGIES EMPLOYED:}

HAND REMOVAL PESTICIDE

PRUNING OTHER

\section{PESTICIDE USE CHECKLIST:}

PRODUCT NAME

PEST TREATED

AMOUNT APPLIED

DATE 
FERTILIZER APPLICATION / NUTRITIONAL PROBLEMS IDENTIFIED ON:

SAMPLE FERTILIZER USE CHECK LIST:

FERTILIZER ANALYSIS $\quad \underline{\text { RATE }}$

RESULTS OF FOLLOW-UP TO INSPECTIONS OR TREATMENT: 